\title{
Post Abortion Care Services in Nigeria
}

\author{
Echendu Dolly Adinma \\ Department Of Community Medicine, Faculty Of Medicine, \\ College Of Health Sciences, Nnamdi Azikiwe University, \\ Nnewi Campus, Nnewi, \\ Anambra State, \\ Nigeria
}

\section{Introduction}

Abortion, whether spontaneous or induced, may be associated with complications that constitute global public health challenge especially in developing countries. In many such countries, abortion is often both unauthorized and unsafe. Only the wealthy and more educated women have access to safe procedures, leaving the poor and often marginalized women to suffer disproportionately, on account of illegal, or restrictive abortion laws (Bankole et al., 2006; Faúndes \& Barzelatto, 2006). In countries with restrictive abortion laws, due to the absence of legal abortion services, women attempt to end unwanted pregnancies through clandestine means. Such women terminate pregnancy by themselves, and sometimes in collaboration with quacks in unhygienic environments (Bankole et al., 2006). The techniques used in most cases are likely to cause morbidities such as genital track trauma, haemorrhage, and infection, or even outright maternal deaths (Ahiadeke, 2001; Rogo, 1993). To compound the problem, when most women in developing countries miscarry or suffer potentially life-threatening complications from unsafe abortion, they rarely have access to prompt treatment (Rogo, 1993). Whereas a woman's life time risk of dying from complications of pregnancy or childbirth in Europe is 1 in 600, it is outrageously high in Africa with figures as high as one in 7 in Ethiopia, for example, with more than half of those deaths attributable to unsafe abortion (WHO, 2001). The risk of death from unsafe abortion in developing countries is the highest in the world with a case fatality rate of $0.7 \%$ for sub-Saharan Africa (WHO, 1998).

Post abortion care (PAC) is a global approach towards solving the problem of maternal mortality and morbidity arising from abortion complications from both spontaneous and induced abortion. It consists of a series of medical and related interventions designed to manage the complications of abortion. Its overall aim is to reduce maternal morbidity and mortality from abortion and its complications, and to improve women's sexual and reproductive health and lives. A comprehensive post abortion care service has been identified to be useful in ameliorating the often adverse health consequences associated with unsafe abortion in regions with restrictive abortion laws. 
This chapter reviews the magnitude of abortion problems together with the place of PAC in the combat of abortion related maternal morbidity and mortality.

\section{Magnitude of abortion problem}

Abortion is one of the most important direct medical causes of maternal mortality, accounting for 12-40 \% of overall global maternal deaths (WHO, 1994; Fatusi \& Ijadunola, 2003). World Health Organization estimates that 46 million induced abortions occur annually the world over (WHO, 1998). To attest to the enormity of this global abortion problem, Henshaw et al., 1998, in a comprehensive review of data on abortion further deduced that one out of every four pregnancies the world over is voluntarily terminated. Conservative estimate from Henshaw et al review of induced abortion indicates that 20 million induced abortions are performed under unsafe circumstances, causing the death of over 80,000 women annually (Henshaw, 1990; Henshaw et al., 1998; Henshaw et al., 1999. This, however, has regional variations, with rates as low as 2 per 1000 occurring in developed countries and as high as 28 per 1000 taking place in developing countries where restrictive abortion laws abound in great proportions (Ahman \& Shah, 2002). In Nigeria with restrictive abortion law for example, Centre for Reproductive Rights reported maternal mortality of 34,000 attributable to abortion in 2008 alone (Centre for Reproductive Rights, 2008)!

Unsafe abortion has human, social and economic costs. While the human cost is related to physical complications that lead to the death of the woman, or associated long term sequelae, the social cost is related to the long-term physical limitations such as infertility, or from moral, legal or cultural stigma that women who abort may suffer. The economic cost is related to the reduction of health resources that would have been used for the management of critical health problems being diverted towards the treatment of abortion complications especially in developing countries (Faúndes \& Barzelatto, 2006).

Every year, more than 4.2 million African women undergo unsafe abortion with an estimated 38,000 of them dying from the experience, leaving countless others with severe morbidities (Henshaw, 1990). These numbers represent over $50 \%$ of all women globally who die from abortion-related causes (WHO, 1998). Amongst those surviving the ordeal, several thousands experience various forms of short- and long-term morbidities. The morbidities include uterine perforation, chronic pelvic pain, and secondary infertility. Victims of unsafe abortion may in addition suffer stigma and isolation forced on them by their families and communities.

Considering the huge contribution of unsafe abortion to the very high maternal mortality in most countries, it is apparent that efforts to reduce maternal mortality and improve maternal health without addressing the issue of unsafe abortion will not succeed.

Only $40 \%$ of the population in the world lives in countries where abortion laws are unrestrictive such that abortion is permissible at the woman's request. The remaining $60 \%$ live in areas with abortion laws of varied restrictions, and most of these are in developing countries (Rahman et al., 1997; Cooks et al., 1999). With only a few exceptions, the abortion 
law in African countries are based on very restrictive 19th century European penal code permitting legal abortions only to save the life of the woman (Henshaw, 1990; Cooks et al., 1999). For example, in Nigeria, abortion law is restrictive and encoded in the portions of the Criminal and Penal codes related to miscarriage, culled from the "British Offence against the persons" Act of 1861 and annotated by S. S. Richardson in 1933, excerpts of which is as follows:

\section{Criminal code act}

This is applicable mainly in Southern Nigeria and includes Sections 228, 229, 230, 297 and 328 of the Criminal code.

\subsection{Section 228}

Any person who, with intent to procure miscarriage of a woman whether she is or is not with child, unlawfully administers to her or causes her to take any poison or other noxious thing, or uses any force of any kind, or uses any other means whatever, is guilty of a felony, and is liable to imprisonment for fourteen years.

\subsection{Section 229}

Any woman who, with intent to procure her own miscarriage, whether she is or is not with child, unlawfully administers to herself any poison or other noxious thing, or uses any force of any kind, or uses any other means whatever, or permits any such thing or means to be administered or used to her, is guilty of a felony, and is liable to imprisonment for seven years.

\subsection{Section 230}

Any person who unlawfully supplies to or procures for any person any thing whatever, knowing that it is intended to be unlawfully used to procure the miscarriage of a woman, whether she is or is not with child, is guilty of a felony, and is liable to imprisonment for three years.

\subsection{Section 297}

A person is not criminally responsible for performing in good faith and with reasonable skill a surgical operation upon any person for his benefit, or upon an unborn child for the preservation of the mother's life, if the performance of the operation is reasonable, having regard to the patient's state at the time and to all the circustances of the case.

\subsection{Section 328}

Any person who, when a woman is about to be delivered of a child, prevents the child from being born alive by any act or omission of such a nature that, if the child had been born alive and had then died, he would be deemed to have unlawfully killed the child, is guilty of a felony, and is liable to imprisonment for life. 


\section{Penal code}

This is applicable to Northern Nigeria:

\subsection{Section 232 - Causing a woman to miscarry}

Whoever voluntarily causes a woman with child to miscarry shall, if such miscarriage be not caused in good faith for the purpose of saving the life of the woman, be punished with imprisonment for a term which may extend to fourteen years or with fine or with both.

\subsection{Section 233 - Causing death of a woman with the intent of causing her miscarriage}

Whoever with intent of causing the miscarriage of a woman whether with child or not does any act which causes the death of such woman, shall be punished:

a. with imprisonment for a term which may extend to fourteen years and shall also be liable to fine and

b. if the act is done without the consent of the woman, with imprisonment for life, or for any less term and shall also be liable to fine.

\subsection{Section 234 - Using force on a woman to cause her miscariage}

Whoever uses force to any woman and thereby unintentionally causes her to miscarry, shall be punished:

a. with imprisonment for a term which may extend to three years or with fine or with both and

b. if the offender knew that the woman was with child, he shall be punished with imprisonment for a term which may extend to five years or with fine or with both.

\subsection{Section 235 - Preventing a child from being born alive}

Whoever before the birth of any child does any act with the intention of thereby preventing that child from being born alive or causing it to die after its birth, shall if such act be not caused in good faith for the purpose of saving the life of the mother, be punished with imprisonment for a term which may extend to fourteen years or with fine or with both.

\subsection{Section 236 - Causing the death of unborn child}

Whoever does any act in such circumstances that, if he thereby caused death, he would be guilty of culpable homicide, and does by such act cause the death of a quick unborn child shall be punished with imprisonment for life or for a less term and shall also be liable to fine (http://annualreview.law.harvard.edu/population/abortion/NIGERIA. abo.htm). 
It is clear from these Codes that the performance of induced abortion in most cases, except when the life of the woman is at risk, in Nigeria constitutes felony punishable with jail terms that my even be as severe as life sentences! The effect of this no doubt is that abortion practice is driven underground creating the enabling environment for the clandestine activities of quacks to flourish.

\section{Evolution of post abortion care}

Post Abortion Care (PAC) was developed to stem the maternal mortality and morbidity arising from unsafe abortions especially in countries with restrictive abortion laws. It is defined as an approach for reducing mortality and morbidity from incomplete and unsafe abortion and resulting complications, and for improving women's sexual and reproductive health and lives (Post abortion Care Consortium Community Task Force, 2002). It was first articulated by Ipas, US based non-governmental organization, in 1991, and later published by the Post Abortion Care Consortium in 1995. However, the role of safe abortion services in the improvement of women's health was recognized in the 1994 International Conference on Population and Development (ICPD). At this conference, participants agreed that "in circumstances where abortion is not against the law, such abortion should be safe. In all cases women should have access to quality services for the management of complications arising from abortion" (ICPD, 1994).

\section{Elements of post abortion care}

The original PAC model consisted of three elements drawn specifically from health care delivery providers perspective without taking due cognizance of the need to accommodate the psychological and physical feelings of the client as well as the community who are the beneficiaries of the services. The three elements of the original PAC model include the following:

1. Emergency treatment services for complications of spontaneous or unsafe induced abortions;

2. Post abortion family planning counseling and services; and

3. Links between emergency abortion treatment services and comprehensive reproductive health care provider perspective.

However in 2001, the PAC Community Task Force expanded the model to five elements, tailored to provide the necessary ingredients for sustainable PAC services by making them more client-oriented. The five elements are:

1. Community and service providers partnership for prevention of unwanted pregnancy and unsafe abortion, together with the mobilization of resources and ensuring that services reflect and meet community expectations and needs;

2. Counseling to identify and respond to women's emotional and physical health needs and other concerns;

3. Treatment of incomplete and unsafe abortion and its complications including the use of manual vacuum aspirator (MVA); 
4. Contraceptive and family planning services to help women prevent an unwanted pregnancy or practice birth spacing; and

5. Linkage to reproductive and other health services that are preferably provided on-site or via referrals to other accessible facilities in the providers' networks.

Women centered post abortion care was developed in 2005 as a step forward from the original PAC. It is a comprehensive approach to meeting each woman's medical and psychosocial needs at the time of treatment for abortion complications. In course of providing women centered post abortion care by health care workers, factors influencing women's need for and access to care such as personal circumstances and living conditions are taken into cognizance to ensure quality service delivery.

PAC has found wide acceptability in developing countries as a very important tool in the combat of maternal mortality from abortion. In countries like Nigeria and Ghana, and many other developing countries of Asia, middle level providers especially Nurse-Midwives have been trained on PAC and have been employed widely in the provision of abortion treatment services especially in rural areas. In Nigeria, Medical Practitioners and Nurse-Midwives both in the private and public health facilities are being trained on the practice of PAC with tremendous success. PAC has also been incorporated by the Nursing and Midwifery Council of Nigeria into the training curriculum of midwifery in Nigeria. PAC training programmes however still need to be better streamlined and more intensified. In a recent survey of 437 health practitioners in southeastern Nigeria, comprising mostly of Doctors and Nurse-Midwives, as high as $75.5 \%$ of the respondents were aware of PAC, although only 35.5\% used manual vacuum aspirator (MVA) (Adinma et al., 2010). In a related survey of 431 health care professionals in the same area, only $41 \%$ had been trained on PAC counseling (Adinma et al., 2010a, 2010b). These attest to the need for the intensification of PAC training programmes to widen the provision of PAC services to all parts of the country.

\section{Conclusion}

The contribution of abortion to high maternal mortality in countries with restrictive abortion laws has made PAC services increasingly relevant particularly in these areas. PAC, for its individualized approach and simplicity of application have been found to be attractive even to middle level health care providers who are readily available in rural areas without the benefit of the services of Medical Doctors. The impact of PAC towards maternal mortality reduction is likely to become evident when a wide coverage of the services is achieved in countries where they are needed. This can be possible when such countries put in place a well packaged PAC training programme made available to all health care practitioners treating abortion to ensure quality services.

\section{References}

Adinma, JIB., Ikeako, L., Adinma, ED., Ezeama, CO., \& Ugboaja, JO. (2010). Awareness and practice of post abortion care services among health care professionals in southeastern Nigeria. The Southeast Asian J of Tropical Medicine and Public Health, 41, 3, 696-704. 
Adinma, JIB., Ikeako, L., Adinma, ED, Ezeama, C., \& Eke, NO. (2010). Post abortion care counseling practiced by health professionals in southeastern Nigeria. International Journal of Gynecology and Obstetrics, 111, 53-56.

Ahiadeke, C. (2001).Incidence of induced abortion in southern Ghana. International Family Planning Perspectives, 27, 2, 96-101.

Ahman, E., \& Shah, I. (2002). Unsafe abortion: worldwide estimates for 2000. Reprod. Health Matters, 10, 13-17.

Bankole, A., Oye-Adeniran, BA., Singh, S., Adewole, IF., Wulf, D., Sedgh, G., \& Hussain, R. (2006).Unwanted pregnancy and induced abortion in Nigeria: causes and consequences, Guttmacher Institutes, 4.

Centre for Reproductive Rights regarding maternal mortality in Nigeria - universal periodic review of Nigeria, August 29 2008: 5.

Cooks, RJ., Dickens, BM., \& Bliss, LE. (1999). International developments in abortion laws from 1988-1998, American Journal of Public Health, 89, 579-586.

Fatusi, AO., \& Ijadunola, KT. (2003). National study on emergency obstetrics care facilities in Nigeria, UNFPA/Federal Ministry of Health, Abuja, Nigeria. 2003.

Faúndes, A., \& Barzelatto, JS. (Eds). (2006). Consequences of unsafe abortion - The human drama of abortion, Vanderbilt University Press, USA, 35.

Henshaw, SK. (1990). Induced abortion: a world review. International Family Planning Perspectives, 22, 76-89.

Henshaw, SK., Singh, S., Oye-Adeniran, BA., Adewole, IF., Iwere, N., \& Cuca, YP. (1998). The incidence of induced abortion in Nigeria. International Family Planning Perspectives, 24, 156-164.

Henshaw, SK., Singh, S., \& Haas, T. (1999). The incidence of abortion worldwide. International Family Planning Perspectives, 24, 30-38.

Post abortion Care Consortium Community Task Force. (2002). Essential elements of post abortion care: An expanded and updated model. PAC in Action 2, Special Supplement, September 2002.

Programme of Action adopted at the International Conference on Population and Development, Cairo, 1994. Paragraph 8.25.

Rahman, A., Katzive, L., \& Henshaw, SK. (1998). A global review of laws on induced abortion, 1985-1997. International Family Planning Perspective, 24, 56-64.

Richardson, SS. (1933). Nigeria abortion law, In: http://annualreview.law.harvard.edu/population/abortion/NIGERIA.abo.htm. (Accessed July 15, 2011).

Rogo, KO. (1993). Induced abortion in sub-Saharan Africa. East African Medical Journal, 70, 6, 386-395.

World Health Organization. (2001). Maternal Mortality in 1995: Estimates developed by WHO, UNICEF and UNFPA. WHO/MSM/01.9 Geneva: WHO, 2001.

World Health Organization.(1998). Unsafe Abortion. Global and Regional estimates of incidence and mortality due to unsafe abortion with a listing of available Country data. Geneva: WHO, 1998. 
World Health Organization. (1994). Mother-Baby-Package: implementing safe motherhood in countries. Practical Guide. Maternal health and safe motherhood programmes, Division of Family Health, WHO, Geneva. 1994. 


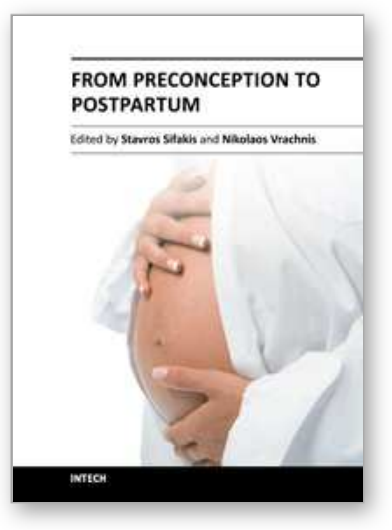

\author{
From Preconception to Postpartum \\ Edited by Dr. Stavros Sifakis
}

ISBN 978-953-51-0353-0

Hard cover, 314 pages

Publisher InTech

Published online 23, March, 2012

Published in print edition March, 2012

Obstetrics is evolving rapidly and finds itself today at the forefront of numerous developments. Providing selected updates on contemporary issues of basic research and clinical practice, as well as dealing with preconception, pregnancy, labor and postpartum, the present book guides the reader through the tough and complex decisions in the clinical management. Furthermore, it deepens the scientific understanding in the pathogenetic mechanisms implicated in pregnancy and motivates further research by providing evidence of the current knowledge and future perspectives in this field. Written by an international panel of distinguished authors who have produced stimulating articles, the multidisciplinary readers will find this book a valuable tool in the understanding of the maternal, placental and fetal interactions which are crucial for a successful pregnancy outcome.

\title{
How to reference
}

In order to correctly reference this scholarly work, feel free to copy and paste the following:

Echendu Dolly Adinma (2012). Post Abortion Care Services in Nigeria, From Preconception to Postpartum, Dr. Stavros Sifakis (Ed.), ISBN: 978-953-51-0353-0, InTech, Available from: http://www.intechopen.com/books/from-preconception-to-postpartum/post-abortion-care-services

\section{INTECH}

open science | open minds

\section{InTech Europe}

University Campus STeP Ri

Slavka Krautzeka 83/A

51000 Rijeka, Croatia

Phone: +385 (51) 770447

Fax: +385 (51) 686166

www.intechopen.com

\section{InTech China}

Unit 405, Office Block, Hotel Equatorial Shanghai

No.65, Yan An Road (West), Shanghai, 200040, China

中国上海市延安西路65号上海国际贵都大饭店办公楼 405 单元

Phone: +86-21-62489820

Fax: +86-21-62489821 
(C) 2012 The Author(s). Licensee IntechOpen. This is an open access article distributed under the terms of the Creative Commons Attribution 3.0 License, which permits unrestricted use, distribution, and reproduction in any medium, provided the original work is properly cited. 